See discussions, stats, and author profiles for this publication at:

https://www.researchgate.net/publication/233516546

\title{
Anatomic Site of Application of Ice-Nucleating Active Bacteria Mfects Supercooling in the Colorado Potato Beetle (Coleoptera: Chrysomelidae)
}

ARTICLE in ENVIRONMENTAL ENTOMOLOGY · MARCH 1996

Impact Factor: 1.3 · DOI: 10.1093/ee/25.2.465

CITATIONS

6
READS

14

5 AUTHORS, INCLUDING:

Jon P Costanzo

Miami University

98 PUBLICATIONS 1,834 CITATIONS

SEE PROFILE 


\title{
Anatomic Site of Application of Ice-Nucleating Active Bacteria Affects Supercooling in the Colorado Potato Beetle (Coleoptera: Chrysomelidae)
}

\author{
RICHARD E. LEE, JR., ${ }^{1}$ KIRA A. STEIGERWALD, ${ }^{2}$ JEFFREY A. WYMAN, ${ }^{3}$ \\ JON P. COSTANZO, ${ }^{1}$ AND MARCIA R. LEE ${ }^{2}$
}

\begin{abstract}
Environ. Entomol. 25(2): 465-469 (1996)
ABSTRACT Most overwintering insects do not survive internal freezing and must avoid low temperatures or enhance the capacity of their body fluids to supercool to survive low temperature exposure. Recent reports have demonstrated that the application of ice-nucleating active microorganisms markedly diminishes supercooling. Topical application of as little as 20 ppm of a suspension of a freeze-dried preparation of the ice-nucleating active bacterium Pseudomonas syringae van Hall was sufficient to elevate the mean supercooling point of the overwintering adults of the Colorado potato beetle, Leptinotarsa decemlineata (Say), from -8.7 to $-4.7^{\circ} \mathrm{C}$. Previous reports have demonstrated that topical application of these biological ice nucleators to insects whose mouths have been sealed still reduces supercooling capacity; however, the anatomical route by which these agents make contact with body water is unclear. Application of the $P$. syringae suspension to the ventral abdomen did not significantly increase the supercooling point $\left(-5.5^{\circ} \mathrm{C}\right)$ compared with beetles treated with the non-ice-nucleating active (control) bacterium Escherichia coli (Migula). However, application of the ice-nucleating agent to the thoracic spiracle, ventral cervix, or abdominal spiracle elevated supercooling point values above those of beetles treated on the ventral abdomen. These data are instructive in the development of methods for the use of ice-nucleating active microorganisms for the biological control of overwintering pests.
\end{abstract}

KEY WORDS Leptinotarsa decemlineata, supercooling capacity, insect cold-hardiness, icenucleating active

BECAUSE MOST OVERWINTERING insects cannot survive internal ice formation they must select protected hibernacula or promote supercooling of their body fluids (Lee 1991). Supercooling refers to the maintenance of the liquid state at temperatures below the freezing point; the lower limit of supercooling, at which temperature ice forms spontaneously, generally is termed the supercooling point or the temperature of crystallization. In some insects the supercooling point may extend $>30^{\circ} \mathrm{C}$ below the freezing point, though more commonly the body fluids of overwintering insects supercool by $5-20^{\circ} \mathrm{C}$. Seasonally, freeze-intolerant insects typically depress their supercooling points before the onset of low winter temperatures.

A number of factors are known to influence supercooling capacity such as physiological status, developmental stage, feeding status, and various environmental factors including photoperiod, temperature, and desiccation stress (Salt 1961, Zachariassen and Hammel 1976, Duman et al. 1985, Bale et al. 1989, Neven et al. 1989). Spontaneous

\footnotetext{
${ }^{1}$ Department of Zoology, Miami University, Oxford, OH 45056.

${ }^{2}$ Department of Microbiology, Miami University, Oxford, $\mathrm{OH}$ 45056 .

${ }^{3}$ Department of Entomology, University of Wisconsin--Madison, 1631 Linden Drive, Madison, WI 53706.
}

ice nucleation within insect body fluids is determined primarily by the activity of internal ice nucleators; more efficient nucleators catalyze ice nucleation at relatively high subzero temperatures. Several species of ice-nucleating active bacteria and fungi have the remarkable capacity to catalyze ice formation at temperatures as high as $-2^{\circ} \mathrm{C}$ (Lindow et al. 1978, Green and Warren 1985, Pouleur et al. 1992). Recent studies have shown that the application of these microorganisms to insects markedly elevates the supercooling point by 10 degrees or more (Fields 1991, 1993; M. R. Lee et al. 1992; R. E. Lee et al. 1993, 1995). These results suggest that ice-nucleating microorganisms may be used for the biological control of overwintering insect pests by decreasing their supercooling capacity and, hence, their chances of winter survival (Strong-Gunderson et al. 1990; Fields 1991, 1993; Lee et al. 1993, 1995).

The Colorado potato beetle, Leptinotarsa decemlineata (Say), is a major pest of potatoes in North America. This species is particularly difficult to control because it has rapidly developed resistance to a broad range of insecticides (Casagrande 1987). In production areas where overwintering adults must survive exposure to low temperatures, the potential exists to employ cultural manipula- 
tions which aggregate beetles into areas where insulating mulch can be removed to create sudden cold shocks to increase winter mortality (Kung et al. 1992, Milner et al. 1992). The use of ice-nucleating bacteria to decrease the capacity of overwintering adults to supercool would enhance the effectiveness of these cold shocks and further increase mortality.

Recent studies have investigated both natural relationships between ice-nucleating active microorganisms and overwintering insects (Kaneko et al. 1991a, b; Lee et al. 1991; Tsumuki et al. 1992) and the use of these organisms for the biological control of insect pests (Strong-Gunderson et al. 1990, 1992, 1994; Fields 1991, 1993; Fields et al. 1993, 1995; Lee et al. 1993, 1995). Application of a freeze-dried preparation of the ice-nucleating active bacterium, Pseudomonas syringae, caused a significant elevation of the supercooling point from -7.6 to $-3.7^{\circ} \mathrm{C}$, when applied to diapausing adults of the Colorado potato beetle (Lee et al. 1994). Although ingestion of the ice-nucleating active bacteria readily causes an elevation of the supercooling point, topical application of the agent to insects whose mouths are sealed to prevent oral intake also has a marked reduction of their supercooling capacity (Strong-Gunderson et al. 1989, 1990). These data suggest that the bacteria readily make contact with insect body water by way of undescribed routes. The purpose of the current study was to determine the effect of applying various concentrations of ice-nucleating active bacteria on the supercooling point of adult beetles and the effect of varying the anatomical site of bacterial application on the supercooling point. These results provide insight concerning the development of procedures for controlling overwintering insect pests.

\section{Materials and Methods}

Sources and Maintenance of Ice-Nucleating Active Agent and Insects. For the dose-response experiment, overwintering adults of the Colorado potato beetles were collected in late August in central Wisconsin, and held unfed at $4^{\circ} \mathrm{C}$, in the dark, in slightly moistened sand. For the anatomic site experiment, adult beetles that had emerged recently from their hibernacula in the spring from similar sites in central Wisconsin were used.

A commercial preparation of lyophilized, UV irradiated $P$. syringae was provided by Genencor (Rochester, NY) and stored at $-20^{\circ} \mathrm{C}$. The P. syringae preparation had an ice-nucleating activity of $2.02 \times 10^{4}$ ice-nucleating sites per gram. Suspensions of this ice-nucleating active bacterium were prepared in sterile distilled water. Escherichia coli (ATCC\# 35421) was obtained from American Type Culture Collection (Rockville, MD) and maintained aerobically at $37^{\circ} \mathrm{C}$ on Bacto Nutrient Agar (Difco, Detroit, MI) with 2.5\% glycerol. Non-icenucleating active E. coli was harvested from 3 -d- old cultures and suspended at a density of $10^{10}$ cells per milliliter in distilled water.

The ice-nucleating activities of the control $E$. coli suspension and the $P$. syringae suspension were assayed by a standard drop-freezing test (Vali 1971, Lindow et al. 1978). For each suspension a set of 40 droplets, each containing $10 \mu \mathrm{l}$ of the control or test suspension, were equilibrated to $0^{\circ} \mathrm{C}$, then cooled at a rate of $0.6^{\circ} \mathrm{C} / \mathrm{min}$ until all of the droplets froze. The temperature at which $50 \%$ of the set of 40 drops froze $\left(\mathrm{T}_{50}\right)$ was determined from a cumulative freezing histogram, and taken as a measure of the ice-nucleating activity of the suspension tested. A 1,000-ppm aqueous suspension of $P$. syringae has a $\mathrm{T}_{50}$ of $-1.8^{\circ} \mathrm{C}$ compared with that of the $E$. coli suspension which had only $-15.1^{\circ} \mathrm{C}$ (Steigerwald et al. 1995).

Insect Treatments. Various concentrations of the ice-nucleating active bacterium $P$. syringae were applied to beetles to determine their effect on the supercooling point. Beetles $(n=11)$ were placed dorsal side up in a sterile petri dish (100 by $15 \mathrm{~mm}$ ) and sprayed with an aqueous suspension (total of 2 ml) containing the ice-nucleating active agent. Distilled water was applied by the same method as a control. Treated beetles were transferred to a sterile, dry petri dish. After allowing $15 \mathrm{~min}$ for the inoculant to dry, no liquid was visible on the surface of the beetle. The beetles were transferred to a 1.5$\mathrm{ml}$ polypropylene microcentrifuge tube and the supercooling point was measured by placing a 36gauge copper-constantan thermocouple in direct contact with the dorsal surface of the insect. These tubes were inserted into glass tubes suspended in a refrigerated bath, equilibrated to $0^{\circ} \mathrm{C}$, and cooled at $\approx 0.6^{\circ} \mathrm{C} / \mathrm{min}$. The cooling profile was recorded using a multichannel data logger (Omega, PM 500), and the supercooling point recorded as the lowest temperature reached before the release of the latent heat of fusion.

To compare the effect on the supercooling point of applying the ice-nucleating active bacterium with various anatomic sites on the adult beetles, a $0.5-\mu \mathrm{l}$ drop of either $10^{10}$ non-ice-nucleating active suspension of $E$. coli per milliliter, or an aqueous suspension containing 20,000 ppm of the ice-nucleating, lyophilized, UV-irradiated P. syringae, was applied to 1 of the following 4 sites: thoracic spiracle, 2nd abdominal spiracle, midline on the ventral abdominal surface, and ventral midline of the cervix between the head and thorax. The beetles were restrained using modeling clay and the drop was applied manually onto the insect using a micropipeter. Because the application of an agent to the thoracic spiracle of $L$. decemlineata required manipulation of the insect wing, sham-operated controls were performed, applying the non-ice-nucleating active agent $E$. coli to the thoracic spiracle. After allowing $15 \mathrm{~min}$ for the beetles to dry, the supercooling point was determined as described above. 


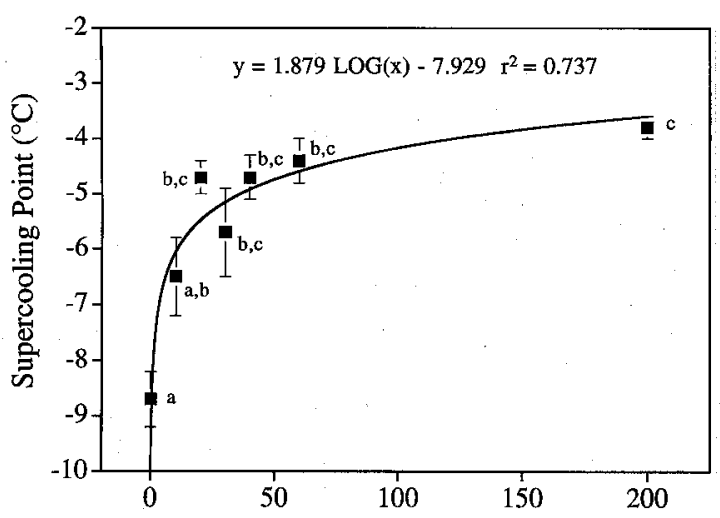

Pseudomonas syringae (ppm)

Fig. 1. Effect of topical application of an aqueous suspension of either distilled water or various concentrations of the ice-nucleating active bacterium $P$. syringae on the supercooling point of the Colorado potato beetle. Supercooling point values were compared using the Kruskal-Wallis test $(H=38.1, P<0.0001)$, and the Dumn multiple comparisons test $(P<0.05)$. Sample size for each treatment was 7-22 individual determinations. Mean values identified by different letters are statistically distinguishable.

Statistical Analysis. Supercooling point values for different treatment groups were compared using the Mann-Whitney or Kruskal-Wallis tests followed by the Dunn multiple comparisons procedures, when appropriate. Significance was judged at $P<0.05$.

\section{Results}

Effect of Bacterial Concentration on the Elevation of the Supercooling Point. All beetles used in this experiment were collected in the autumn immediately before overwintering in reproductive diapause. The mean \pm SEM supercooling point of beetles sprayed with distilled water was $-8.7 \pm 0.5^{\circ} \mathrm{C}$, with individual values ranging from -6.1 to $-10.9^{\circ} \mathrm{C}$. Small volumes of distilled water normally supercool extensively, typically remaining unfrozen to $-15^{\circ} \mathrm{C}$ or below. The beetles treated with distilled water thus served as a non-ice-nucleating active control for the $P$. syringae suspensions and for the possible effects of moisture on the surface of the insect.

The purpose of this experiment was to determine the minimum concentration of $P$. syringae that was effective in elevating the supercooling point (Fig. 1). Although a suspension of $10 \mathrm{ppm} P$. syringae did not significantly elevate the supercooling point $\left(-6.5 \pm 0.7^{\circ} \mathrm{C}\right)$ above that of the control, a $20-\mathrm{ppm}$ suspension significantly increased the supercooling point to $-4.7 \pm 0.3^{\circ} \mathrm{C}$, with individual values ranging from -3.1 to $-8.1^{\circ} \mathrm{C}$. The highest concentration $(200 \mathrm{ppm})$ used in this study produced a mean supercooling point of $-3.8 \pm$ $0.2^{\circ} \mathrm{C}$. Furthermore, at this concentration $>1 / 2$ of
Table 1. Mean supercooling point \pm SEM after application of an aqueous suspension of either a non-ice-nucleating active bacterial control $E$. coli or the ice-nucleating active $P$. syringae to 4 anatomic sites on the Colorado potato beetle

\begin{tabular}{|c|c|c|c|}
\hline $\begin{array}{l}\text { Treat- } \\
\text { ment }\end{array}$ & $\begin{array}{l}\text { Anatomic site } \\
\text { of application }\end{array}$ & $n$ & Temp, ${ }^{\circ} \mathrm{C}$ \\
\hline \multicolumn{4}{|c|}{ E. coli (non-ice-nucleating active bacterial control) } \\
\hline & Thoracic spiracle & 28 & $-6.5 \pm 0.2 \mathrm{a}$ \\
\hline \multicolumn{4}{|c|}{ P. syringae (ice-nucleating active bacterium) } \\
\hline & Ventral abdomen & 32 & $-5.5 \pm 0.2 \mathrm{a}, \mathrm{b}$ \\
\hline & Abdominal spiracle & 32 & $-4.7 \pm 0.2 b, c$ \\
\hline & Ventral cervix & 20 & $-5.1 \pm 0.3 \mathrm{~b}, \mathrm{c}$ \\
\hline & Thoracic spiracle & 26 & $-4.5 \pm 0.3 \mathrm{c}$ \\
\hline
\end{tabular}

Supercooling point values were compared using the KruskalWallis nonparametric test $(H=33.4, P<0.0001)$, and the Dunn multiple comparisons test $(P<0.05)$. Mean values identified by different letters are statistically distinguishable.

the beetles had supercooling points at or above $-3.3^{\circ} \mathrm{C}$ with values as high as $-2.9^{\circ} \mathrm{C}$.

Anatomic Site of Bacterial Application. The supercooling points of untreated beetles that had recently emerged from overwintering ranged from -4.1 to $-7.7^{\circ} \mathrm{C}$. The mean, $-6.6 \pm 0.2^{\circ} \mathrm{C}$, was not significantly different (Mann-Whitney, $U=273.0$, $P=0.68$ ) from beetles treated with the non-icenucleating control suspension of $E$. coli, $-6.5 \pm$ $0.2^{\circ} \mathrm{C}$. The suspension of $E$. coli applied to the thoracic spiracle served as a control for possible effects of insect manipulation, surface moisture, and bacterial suspension.

Significant differences occurred among the 4 groups treated with $P$. syringae and the control group treated with $E$. coli (Table 1; Kruskal-Wallis, $H=33.4, P<0.0001$ ). Application of the $P$. syringae suspension to the ventral abdomen resulted in a mean supercooling point $\left(-5.5 \pm 0.2^{\circ} \mathrm{C}\right.$; range, -3.2 to $-7.4^{\circ} \mathrm{C}$ ) that was not significantly different from beetles treated with the non-ice-nucleating active bacterium $E$. coli. However, treatment of the thoracic spiracle with $P$. syringae produced supercooling point values $\left(-4.5 \pm 0.3^{\circ} \mathrm{C}\right)$ that were significantly higher than those of beetles treated on the ventral abdomen, but similar to values for beetles treated on the ventral cervix and abdominal spiracle (Table 1 ). In the thoracic spiracle treatment group some individuals froze at temperatures as high as $-2.5^{\circ} \mathrm{C}$, whereas half of the 22 individuals froze above $-4^{\circ} \mathrm{C}$.

\section{Discussion}

Previous investigations have demonstrated that ice-nucleating active bacteria or fungi can be used to decrease the supercooling capacity of insects from at least 5 orders of insects (Coleoptera, Diptera, Hemiptera, Homoptera, and Lepidoptera) represented by $>18$ species (Lee et al. 1992, 1993, 1995; unpublished data). This study examined the efficacy of using an ice-nucleating active bacterium to decrease insect cold-hardiness by reducing the 
supercooling capacity. Adults of the freeze-intolerant Colorado potato beetle were treated with the ice-nucleating active bacterium $P$. syringae to determine the effect of treatment dose and the anatomic site of application on the supercooling point.

Dose Response. As the concentration of bacteria applied to the beetles increased their supercooling capacity decreased. At the highest treatment concentration of $200 \mathrm{ppm}$ the supercooling point increased $>4.9^{\circ} \mathrm{C}$. The minimum concentration tested that produced a significant increase in the supercooling point was $20 \mathrm{ppm}$. Previous studies have reported similar trends with increasing doses of icenucleating active bacteria. Fields (1991) found that chilling mortality of the rusty grain beetle, Cryptolestes ferrugineus (Stephens), was directly correlated with the ice-nucleating activity of the bacterial application. Surface application of ice-nucleating active bacteria using either a dry formulation or a suspension of ice-nucleating active bacteria decreases supercooling capacity in a dose-dependent manner for at least 7 other stored product pests (R. E. Lee et al. 1992). The current study also extends our previous work with the Colorado potato beetle in which we demonstrated that supercooling points increase when beetles were exposed to the dried preparation of P. syringae mixed with soil (R. E. Lee et al. 1994). During the $2 \mathrm{yr}$ of that study the supercooling point values increased by $\approx 3.5-3.9^{\circ} \mathrm{C}$ when treated with $1,000 \mathrm{ppm}$ (wt:wt) of the P. syringae preparation in soil, compared with the current study in which a topically applied suspension of $200 \mathrm{ppm}$ increased supercooling points by $2.7^{\circ} \mathrm{C}$.

Anatomic Site of Bacterial Application. At least in hindsight, it was perhaps not remarkable that ingestion of potent biological ice-nucleating agents should induce ice nucleation in insects at significantly higher temperatures. However, it was surprising that the application of these nucleators to insects whose mouths are sealed to prevent ingestion should also readily elevate the supercooling point. In cold-hardy, overwintering adults of the lady beetle Hippodamia convergens Guérin-Méneville, whose mouths had been sealed, application of an ice-nucleating active bacterial suspension markedly increased their supercooling points (Strong-Gunderson et al. 1989, 1990). These results suggest that the ice-nucleating agents readily made contact with the body of water of the insects via some unidentified route.

The current study examined the efficacy of several potential routes by which externally applied ice-nucleating active bacteria might make contact with insect body water. Our data demonstrate that the extent of supercooling point elevation differed among the sites of application. Application of a 0.5$\mu l$ drop of the $P$. syringae solution to the ventral abdomen did not significantly elevate the supercooling point relative to the $E$. coli control. However, supercooling points for the thoracic and abdominal spiracles and the ventral cervix groups were significantly higher than for the $E$. coli control. These results are consistent with similar studies using $H$. convergens in which ventral abdominal applications did not significantly increase values relative to controls (Steigerwald et al. 1995).

The cuticle covering the ventral sternites is relatively thick compared with elsewhere on the integument, which may explain why application of $P$. syringae to this site had little effect on the supercooling point. The spiracles open to the outside of the body for the exchange of respiratory gases between the insect and the atmosphere. Since the spiracles are rather large openings into the tracheal system which has a moist lining and ends in fluidfilled tracheoles, it is likely that the externally applied bacteria may reach body water by way of these openings. In $H$. convergens application of ice-nucleating active bacteria to the thoracic spiracle was more effective in elevating the supercooling point than treatment of the abdominal spiracle (Steigerwald et al. 1995). One explanation suggested for this difference is that the thoracic spiracle has a greater diameter than the abdominal spiracle. Second, the surface tension of the bacterial solution would be expected to provide greater resistance to entry in the smaller-diameter abdominal spiracle. In the Colorado potato beetle the maximum diameter of the thoracic spiracle 0.56 $\mathrm{mm}$ ) is approximately twice that of the abdominal spiracle. Although in the current study mean supercooling points did not differ significantly between the thoracic and abdominal spiracle treatment groups, this may be accounted for by the rather considerable variability in supercooling points among individuals and by the relatively high supercooling points $\left(-6.5^{\circ} \mathrm{C}\right)$ of untreated Colorado potato beetle compared with $H$. convergens that supercools to $\approx-16^{\circ} \mathrm{C}$ (Steigerwald et al. 1995).

Previously, we reported that the addition of a surfactant may increase the efficacy of ice-nucleating microorganisms in elevating the supercooling point (Lee et al. 1993). It is possible that in this case the surfactant functioned to decrease the surface tension and facilitated entry of the bacterial suspension into the spiracles or other sites on the body. Lastly, the use of surfactant in combination with ice-nucleating bacteria may be useful in the development of biological control methods for decreasing the overwintering survival of Colorado potato beetles (Lee et al. 1995).

The report further documents that the supercooling capacity and cold-hardiness of overwintering, freeze-intolerant insects may be reduced using ice-nucleating active microorganisms. These data also suggest that the spiracles and anatomic sites other than the mouth may serve as avenues by which these biological ice nucleators may contact body water and inhibit supercooling.

\section{Acknowledgments}

We thank the anonymous reviewers for their helpful comments on the manuscript. This study was supported 
in part by Cooperative State Research Service, USDA grant 93-37302-9003, NSF IBN-9305809, and Genencor International Incorporated.

\section{References Cited}

Bale, J. S., T. N. Hansen, and J. G. Baust. 1989. Nucleators and sites of nucleation in the freeze tolerant larvae of the gallfly Eurosta solidaginis (Fitch). J. Insect Physiol. 35: 291-298.

Casagrande, R. A. 1987. The Colorado potato beetle: 125 years of mismanagement. Bull. Entomol. Soc. Am. 33: 142-150.

Duman, J. G., L. G. Neven, J. M. Beals, K. R. Olson, and F. J. Castellino. 1985. Freeze-tolerance adaptations, including haemolymph protein and lipoprotein nucleators, in the larvae of the cranefly Tipula trivittata. J. Insect Physiol. 31: 1-8.

Fields, P. G. 1991. The cold-hardiness of Cryptolestes ferrugineus and the use of ice nucleation-active bacteria as a cold-synergist, pp. 1183-1191. In F. FleuratLessard and P. Ducon [eds.], Proceedings of the 5th International Working Conference on Stored-Product Protection, vol. 2. Bordeaux, France.

1993. Reduction of cold tolerance of stored-product insects by ice-nucleating-active bacteria. Environ. Entomol. 22: 470-476.

Fields, P. G., S. Pouleur, and C. Richard. 1993. Stability of ice-nucleating bacteria and fungus as a means of reducing the cold-hardiness of insect pests. Cryobiology 30:623.

1995. The effect of high temperature storage on the capacity of an ice-nucleating-active bacterium and fungus to reduce insect cold-tolerance. Can. Entomol. 127: $33-40$.

Green, R. L., and G. J. Warren. 1985. Physical and functional repetition in a bacterial ice nucleation gene. Nature (Lond.) 317: 645-648.

Kaneko, J., K. Kita, and K. Tanno. 1991a. Ice nucleating active bacteria isolated from the diamondback moth, Plutella xylostella L. pupae (Lepidoptera: Ypononeutidae). Jpn. J. Appl: Entomol. Zool. 35: 7-11.

Kaneko, J., T. Yoshida, T. Owada, K. Kita, and K. Tamno. 1991b. Erwinia herbicola: ice nucleation active bacteria isolated from diamondback moth, Plutella xylostella L. pupae. Jpn. J. Appl. Entomol. Zool. 35: 247-251.

Kung, K.-J. S., M. Milner, J. A. Wyman, J. Feldman, and E. Nordheim. 1992. Survival of Colorado potato beetle (Coleoptera: Chrysomelidae) after exposure to subzero thermal shocks during diapause. J. Econ. Entomol. 85: 1695-1700.

Lee, M. R., R. E. Lee, J. M. Strong-Gunderson, and S. R. Minges. 1992. Treatment with ice nucleating active fungi and surfactants decreases insect supercooling capacity. Cryobiol. 29: 743 (abstr.).

Lee, R. E. 1991. Principles of insect low temperature tolerance, pp. 17-46. In R. E. Lee and D. L. Denlinger [eds.], Insects at low temperature. Chapman \& Hall, New York.

Lee, R. E., J. M. Strong-Gunderson, M. R. Lee, K. S. Grove, and T. J. Riga. 1991. Isolation of ice nucleating active bacteria from insects. J. Exp. Zool. 257: 124-127.

Lee, R. E., J. M. Strong-Gunderson, M. R. Lee, and E. C. Davidson. 1992. Ice-nucleating active bac- teria decrease the cold-hardiness of stored grain insects. J. Econ. Entomol. 85: 371-374.

Lee, R. E., M. R. Lee, and J. M. Strong-Gunderson. 1993. Insect cold-hardiness and ice nucleating active microorganisms including their potential use for biological control. J. Insect Physiol. 39: 1-12

Lee, R. E., J. P. Costanzo, P. E. Kaufman, M. R. Lee, and J. A. Wyman. 1994. Ice-nucleating active bacteria reduce the cold-hardiness of the freeze-intolerant Colorado potato beetle (Coleoptera: Chrysomelidae). J. Econ. Entomol. 87: 377-381.

Lee, R. E., M. R. Lee, and J. M. Strong-Gunderson. 1995. Biological control of insect pests using ice nucleating microorganisms, pp. 257-259. In R. E. Lee, G. J. Warren, and L. V. Gusta [eds.], Biological ice nucleation and its applications. APS, St. Paul, MN.

Lindow, S. E., D. C. Arny, and C. D. Upper. 1978. Erwinia herbicola: a bacterial ice nucleus active in increasing frost injury to corn. Phytopathology 68: 523527.

Milner, M., K.-J.S. Kung, J. A. Wyman, J. Feldman, and E. Nordheim. 1992. Enhancing overwintering mortality of Colorado potato beetle (Coleoptera: Chrysomelidae) by manipulating the temperature of its habitat. J. Econ. Entomol. 85: 1701-1708.

Neven, L. G., J. G. Duman, M. G. Low, L. C. Sehl, and F. J. Castellino. 1989. Purification and characterization of an insect hemolymph lipoprotein ice nucleator: evidence for the importance of phosphatidylinositol and apolipoprotein in the ice nucleator activity. J. Comp. Physiol. B 159: 71-82.

Pouleur, S., C. Richard, J. Martin, and H. Antoun. 1992. Ice nucleation activity in Fusarium acuminatum and Fusarium avenaceum. Appl. Environ. Microbiol. 58: 2960-2964.

Salt, R. W. 1961. Principles of insect cold-hardiness. Annu. Rev. Entomol. 6: 55-74.

Steigerwald, K. A., M. R. Lee, R. E. Lee, and J. C. Marshall. 1995. Effect of biological ice nucleators on insect supercooling capacity varies with anatomic site of application. J. Insect Physiol. 41: 603-608.

Strong-Gunderson, J. M., R. F. Lee, and M. R. Lee. 1989. Ice nucleating bacteria promote transcuticular nucleation in insects. Cryobiology 26: 551 (abstr.).

Strong-Gunderson, J. M., R. E. Lee, M. R. Lee, and T. J. Riga. 1990. Ingestion of ice-nucleating bacteria increases the supercooling point of the lady beetle Hippodamia convergens. J. Insect Physiol. 36: 153-157.

Strong-Gunderson, J. M., R. E. Lee, and M. R. Lee. 1992. Topical application of ice nucleating active bacteria decreases insect cold tolerance. Appl. Environ. Microbiol, 58: 2711-2716.

1994. Ice nucleating active bacteria increase insect mortality at high subzero temperatures. Cryo-Letters 15: 385-392.

Tsumuki, H., H. Konno, T. Maeda, and Y. Okamoto. 1992. An ice-nucleating active fungus isolated from the gut of the rice stem borer, Chilo suppressalis Walker (Lepidoptera: Pyralidae). J. Insect Physiol. 38: $119-125$.

Vali, G. 1971. Quantitative evaluation of experimental results on the heterogeneous freezing nucleation of supercooled liquids. J. Atmos. Sci. 28: 402-409.

Zachariassen, K. E., and H. T. Hammel. 1976. Nucleating agents in the haemolymph of insects tolerant to freezing. Nature (Lond.) 262: 285-287.

Received for publication 30 August 1995; 28 December 1995. 